\title{
Phosphate sorption and desorption by two contrasting volcanic soils of equatorial Africa
}

\author{
Sara Gonzalez-Rodriguez ${ }^{1}$, Maria Luisa Fernandez-Marcos ${ }^{\text {Corresp. } 1,2}$ \\ 1 Department of Soil Science and Agricultural Chemistry, Universidad de Santiago de Compostela, Lugo, Spain \\ 2 Institute of Agricultural Biodiversity and Rural Development, University of Santiago de Compostela, Lugo, Spain \\ Corresponding Author: Maria Luisa Fernandez-Marcos \\ Email address: mluisa.fernandez@usc.es
}

Volcanic soils cover $1 \%$ of the Earth's surface but support $10 \%$ of the world's population. They are among the most fertile soils in the world, due to their excellent physical properties and richness in available nutrients. The major limiting factor for plant growth in volcanic soils is phosphate fixation, which is mainly attributable to active species of aluminium and iron. The sorption and desorption of phosphate is studied on the surface horizons of two African agricultural soils, a silandic Andosol (Rwanda) and a vitric Andosol (São Tomé and Principe). Both soils are slightly acid. The silandic Andosol is rich in active aluminium forms, while the vitric Andosol has high amounts of crystalline iron and aluminium oxides. Sorption isotherms were determined by equilibrating at $293 \mathrm{~K}$ soil samples with phosphate solutions of concentrations between 0 and $100 \mathrm{mg} \mathrm{PL} \mathrm{L}^{-1}$ in $\mathrm{NaNO}_{3}$; phosphate was determined by visible spectrophotometry in the equilibrium solution. To study desorption, the soil samples from the sorption experiment were equilibrated with $0.02 \mathrm{M} \mathrm{NaNO}_{3}$. The isotherms were adjusted to mathematical models. In almost all the concentration range, the adsorption of phosphate by the silandic Andosol was greater than $90 \%$ of the amount added, being lower in the vitric Andosol but always higher than $65 \%$. The high sorption by the silandic Andosol is attributed to its richness in non-crystalline Fe and Al, while in the vitric Andosol crystalline iron species seem to play a relevant role in the adsorption. The sorption isotherms of both soils fitted to the Temkin model, the adjustment to the Langmuir or Freundlich models being unsatisfactory; throughout the range studied, the sorption increases with increasing phosphorus concentration, a maximum sorption is not predictable (as occurs when the sorption is adjusted to the Langmuir model). For an added $\mathrm{P}$ concentration of $100 \mathrm{mg} \mathrm{L}^{-1}\left(3.2 \mathrm{mmol} \mathrm{L}^{-1}\right)$, the sorption is $47.7 \mu \mathrm{mol} \mathrm{P} \mathrm{g}^{-1}$ in the silandic Andosol and $41.6 \mu \mathrm{mol} \mathrm{P} \mathrm{g}^{-1}$ in the vitric Andosol. The desorption is low and the comparison of the sorption and desorption isotherms reveals a pronounced hysteresis, that is, the irreversibility of the sorption. The high phosphate sorption and its irreversibility are comparable to those published for other volcanic soils 
with high contents of allophane, active aluminium and free iron. The strong phosphate adsorption is a serious limiting factor for plant growth, which requires a careful management of phosphorus fertilization. 


\section{Phosphate sorption and desorption by two contrasting 2 volcanic soils of equatorial Africa}

3 Sara González-Rodríguez ${ }^{1}$, Maria Luisa Fernández-Marcos ${ }^{1,2}$

$4{ }^{1}$ Department of Soil Science and Agricultural Chemistry, University of Santiago de Compostela, 27002

5 Lugo, Spain

$6{ }^{2}$ Institute of Agricultural Biodiversity and Rural Development, University of Santiago de Compostela,

727002 Lugo, Spain

8

9 Corresponding Author:

10 Maria Luisa Fernández-Marcos

11 Department of Soil Science and Agricultural Chemistry, University of Santiago de Compostela, 27002

12 Lugo, Spain

13 Email address: mluisa.fernandez@usc.es 


\section{ABSTRACT}

Volcanic soils cover $1 \%$ of the Earth's surface but support $10 \%$ of the world's population. They are among the most fertile soils in the world, due to their excellent physical properties and richness in available nutrients. The major limiting factor for plant growth in volcanic soils is phosphate fixation, which is mainly attributable to active species of aluminium and iron.

The sorption and desorption of phosphate is studied on the surface horizons of two African agricultural soils, a silandic Andosol (Rwanda) and a vitric Andosol (São Tomé and Principe). Both soils are slightly acid. The silandic Andosol is rich in active aluminium forms, while the vitric Andosol has high amounts of crystalline iron and aluminium oxides. Sorption isotherms were determined by equilibrating at $293 \mathrm{~K}$ soil samples with phosphate solutions of concentrations between 0 and $100 \mathrm{mg} \mathrm{P} \mathrm{L}^{-1}$ in $\mathrm{NaNO}_{3}$; phosphate was determined by visible spectrophotometry in the equilibrium solution. To study desorption, the soil samples from the sorption experiment were equilibrated with $0.02 \mathrm{M} \mathrm{NaNO}_{3}$. The isotherms were adjusted to mathematical models.

In almost all the concentration range, the adsorption of phosphate by the silandic Andosol was greater than $90 \%$ of the amount added, being lower in the vitric Andosol but always higher than $65 \%$. The high sorption by the silandic Andosol is attributed to its richness in non-crystalline Fe and Al, while in the vitric Andosol crystalline iron species seem to play a relevant role in the adsorption. The sorption isotherms of both soils fitted to the Temkin model, the adjustment to the Langmuir or Freundlich models being unsatisfactory; throughout the range studied, the sorption increases with increasing phosphorus concentration, a maximum sorption is not predictable (as occurs when the sorption is adjusted to the Langmuir model).

For an added $\mathrm{P}$ concentration of $100 \mathrm{mg} \mathrm{L}^{-1}\left(3.2 \mathrm{mmol} \mathrm{L}^{-1}\right)$, the sorption is $47.7 \mu \mathrm{mol} \mathrm{P} \mathrm{g}^{-1}$ in the silandic Andosol and $41.6 \mu \mathrm{mol} \mathrm{P} \mathrm{g}{ }^{-1}$ in the vitric Andosol. The desorption is low and the comparison of the sorption and desorption isotherms reveals a pronounced hysteresis, that is, the irreversibility of the sorption. The high phosphate sorption and its irreversibility are comparable to those published for other volcanic soils with high contents of allophane, active aluminium and free iron.

The strong phosphate adsorption is a serious limiting factor for plant growth, which requires a careful management of phosphorus fertilization. 


\section{INTRODUCTION}

50 Volcanic soils cover 1\% of the Earth's surface but support 10\% of the world's population (Neall, 51 2009). These soils are among the most fertile in the world, due to their excellent physical 52 properties and their richness in available nutrients. From the chemical point of view, their major 53 limitation is phosphate fixation, attributable mainly to active species of aluminium and iron 54 (Nanzyo, 2002).

Adsorption of oxyanions by soils and mineral surfaces has received considerable attention (Adegoke et al., 2013; Gasparatos et al., 2006; Jiang et al., 2015; Kumar et al., 2016; Parfitt, 1979), due to their role as nutrients or pollutants. Mineral surfaces, particularly those of metal (hydr)oxides, can adsorb oxyanions by specific and non-specific complexation mechanisms (Goldberg and Johnston, 2001). Specifically adsorbed oxyanions are strongly bound to the surface through covalent bonds formed by ligand exchange with surface $\mathrm{OH}$ groups (inner sphere complexes). Non-specifically adsorbed oxyanions bind weakly to the surface by electrostatic attraction through an interposed water molecule (outer sphere complexes).

Soil available phosphorus is constituted by phosphorus in the soil solution plus the so-called labile phosphorus, which easily passes from the soil solid phase into solution. The specific adsorption of phosphate by active soil surfaces transforms it into non-labile, hence non-available, phosphorus.

The presence of active forms of aluminium and iron, such as oxides, oxyhydroxides, short-range order silicates (allophane, imogolite), $\mathrm{Al}(\mathrm{Fe})$-humus complexes, is a characteristic of volcanic soils. These materials confer the soil the ability to adsorb phosphate. Phosphate fixation by iron and aluminium oxides or allophane is a limiting factor for plant growth, given the condition of essential nutrient of phosphorus (Sanchez et al., 2003). The high phosphate fixation by iron and aluminium oxides can be shown by a value of iron extractable by dithionite-citrate higher than $4 \%$ and leads to phosphate fertilization needs of more than $100 \mathrm{mg} \mathrm{P} \mathrm{kg}^{-1}$. The high phosphate fixation by allophane or imogolite can be evidenced by a value of $\mathrm{pH}$ in $\mathrm{NaF}$ higher than 10 and leads to phosphate fertilization needs of more than $200 \mathrm{mg} \mathrm{P} \mathrm{kg}$.

In Rwanda, the most densely populated country in Africa, volcanic soils occupy an area of 700 with an area of $857 \mathrm{~km}^{2}$, is a small volcanic island, mainly basaltic in nature, near the West African coast, which is part of the volcanic alignment known as the Cameroon Hot Line 80 (Deruelle et al., 2007).

81 Volcanic soils have been extensively studied in the world, particularly with respect to 82 phosphorus adsorption (Van Ranst et al., 2004; Auxtero et al., 2008; Hashimoto et al., 2012; 83 Valle et al., 2015), but there is a dearth of information on volcanic soils in Africa. A number of 
published papers address the phosphate sorption by African soils (Sibanda and Young, 1986; Loganathan et al., 1987; Frossard et al., 1992; Adepoju, 1993; Arduino et al., 1993; Adetjuni, 1997; Henry and Smith, 2003; Nwoke et al., 2003; Gichangi et al., 2008). A few papers deal with phosphate adsorption by African volcanic soils: Duffera and Robarge (1999) studied P sorption by four highland soils of Ethiopia, among which an Andosol developed from volcanic ash. Gimsing et al. (2007) reported the sorption of phosphate and glyphosate by four variable-charge Tanzanian soils, including an Andosol. Siéwé et al. (2008) studied the phosphate adsorption by an Andosol of the Bambouto Mountains (Cameroon). Woumfo et al. (2015) investigated the usefulness of an Andosol from Bambouto Mountain (Cameroon) as an adsorbent to remove phosphorus from polluted waters. As far as we know, there are no published studies on $\mathrm{P}$ desorption in African soils.

Phosphate sorption capacity is a principal factor regulating $\mathrm{P}$ concentration in the soil solution and hence available phosphorus. Understanding the $\mathrm{P}$ sorption and release characteristics of soils is important in determining the fate of applied $\mathrm{P}$ fertilizer. Correcting $\mathrm{P}$ deficiencies by fertilizer application must take into account the P fixation characteristics of the soil (Duffera et al., 1999). Phosphorus sorption by soils must be considered not only to determine the $\mathrm{P}$ fertilizing requirement but also the management of phosphate fertilizers. This is of paramount importance in developing countries, where the price of fertilizers often restricts the possibility of fertilizing agricultural fields.

In order to contribute to a better management of phosphorus fertilization in African volcanic soils under a changing environment, this paper aims to study the phosphate sorption and desorption by the surface horizons of two agricultural soils of equatorial Africa, a silandic Andosol (IUSS Working Group WRB, 2014) on volcanic ash (Rwanda) and a vitric Andosol on basaltic material (São Tomé and Principe). Silandic Andosols are characterized by their richness in short-range-order silicates (allophane, imogolite), while vitric Andosols are characterized by the presence of volcanic glass and a lower content of short-range-order minerals (lesser degree of weathering).

\section{MATERIALS AND METHODS}

\section{Soils}

The surface horizons $(0-20 \mathrm{~cm})$ of two agricultural soils located in Rwanda and São Tomé and Príncipe were used in the study. The first one, developed from volcanic ash, classifies as silandic Andosol (IUSS Working Group WRB, 2014), while the soil of São Tomé Island classifies as vitric Andosol. The geographic location and some relevant properties of the two studied soils are presented in Table 1 . The aluminium extracted by acid oxalate $\left(\mathrm{Al}_{\mathrm{o}}\right)$ estimates the "active aluminium" (aluminium in organic complexes, in non-crystalline hydrated oxides, in allophane and imogolite) (Garcia-Rodeja et al., 2004; Parfitt and Childs, 1988). The iron extracted by acid 
121 oxalate $\left(\mathrm{Fe}_{\mathrm{o}}\right)$ corresponds essentially to ferrihydrite (Nanzyo, 2002; Parfitt and Childs, 1988).

122 The concentrations of aluminium and iron extractable by acid oxalate fulfil the requirement for

123 andic properties $\left(\mathrm{Al}_{\mathrm{o}}+1 / 2 \mathrm{Fe}_{\mathrm{o}}>2 \%\right.$; IUSS, 2014) in the soil of Rwanda and for vitric properties

$124\left(\mathrm{Al}_{\mathrm{o}}+1 / 2 \mathrm{Fe}_{\mathrm{o}}: 0.4-2 \%\right)$ in the soil of São Tomé.

125 The dithionite-citrate extracts the total free iron $\left(\mathrm{Fe}_{\mathrm{d}}\right)$, including non-crystalline forms of iron

$126\left(\mathrm{Fe}_{\mathrm{o}}\right)$ and crystalline oxyhydroxides (goethite, hematite, magnetite ...) (García-Rodeja et al.,

127 2007; Parfitt and Childs, 1988). The aluminium extracted by dithionite-citrate $\left(\mathrm{Al}_{\mathrm{d}}\right)$ includes

128 non-crystalline aluminium forms (although it is ineffective in the extraction of non-crystalline

129 aluminosilicates) as well as aluminium occluded in crystalline iron oxyhydroxides (García-

130 Rodeja et al., 2007). The concentration of $\mathrm{Fe}_{\mathrm{d}}$ in the São Tomé's vitric Andosol (7.84\%) is rather

131 high, according to Sanchez et al. (2003). This soil presents moderate concentrations of non-

132 crystalline Fe and Al, but a large amount of crystalline iron oxyhydroxides (Table 1). On the

133 other hand, the silandic Andosol of Rwanda has a $\mathrm{Fe}_{\mathrm{o}} / \mathrm{Fe}_{\mathrm{d}}$ ratio of 0.75 , indicating the

134

135

136

predominance of non-crystalline forms of iron over crystalline forms. In the São Tomé vitric

Andosol, the aluminium extractable by dithionite-citrate is higher than that extractable by acid

137

oxalate, which indicates the presence of aluminium in the crystalline lattices of iron

oxyhydroxides.

138

139

Values of $\mathrm{pH}$ in $\mathrm{NaF}$ higher than 9.5 indicate the presence of allophane and/or organo-aluminium complexes (IUSS, 2014), materials active in the fixation of anions.

The soil samples were air-dried and sieved $(<2 \mathrm{~mm})$ prior to analysis.

\section{Sorption and desorption isotherms}

143

144

145

146

147

148

149

150

151

152

153

154

155

156
To determine the sorption isotherms, $0.5 \mathrm{~g}$ of soil were equilibrated with $10 \mathrm{~mL}$ of solution of phosphate in $0.02 \mathrm{M} \mathrm{NaNO}_{3}$ as background electrolyte at room temperature $(293 \mathrm{~K}) . \mathrm{P}$

concentrations in equilibrating solutions ranged between 0 and $100 \mathrm{mg} \cdot \mathrm{L}^{-1}(0,2,4,10,20,40,60$ and $100 \mathrm{mg} \mathrm{L}^{-1}$ ) and the solution $\mathrm{pH}$ was adjusted to the value of soil $\mathrm{pH}$. The suspensions were shaken for $24 \mathrm{hrs}$, centrifuged at $6000 \mathrm{rpm}$. for 15 minutes, and filtered through acid-washed filter paper. The determinations were carried out in triplicates. Phosphorus was determined in the equilibrium solution by visible spectrophotometry with molybdate by the ascorbic acid-reduced method (Kuo, 1996). Adsorbed phosphorus was calculated as the difference between added $\mathrm{P}$ and $\mathrm{P}$ in the equilibrium solution.

Desorption experiments were carried out in soil samples previously equilibrated with various phosphate concentrations. After removing the supernatant solution, $10 \mathrm{~mL}$ of $0.02 \mathrm{M} \mathrm{NaNO}_{3}$ solution adjusted to the soil $\mathrm{pH}$ were added, the suspensions shaken for $24 \mathrm{hrs}$, centrifuged at $6000 \mathrm{rpm}$. for 15 minutes, and filtered through acid-washed filter paper. Phosphorus was determined in the equilibrium solution as in the sorption experiments. The $\mathrm{P}$ concentration 
157 remaining in the adsorbed phase was calculated from the concentration adsorbed after the

158

159

160

161

162

163

164

165

166

167

168

169

170

171

172

173

174

175

176

177

178

179

180

181

182

183

184

185

186

187

188

189

190

191

sorption equilibrium and the concentration released to the solution, making a correction to take into account the solution embedded in the solid after sorption equilibrium.

Sorption and desorption isotherms were obtained by plotting the phosphorus concentration in the adsorbed phase versus the solution concentration at equilibrium. The isotherms were fitted to mathematical models, namely the Langmuir, Freundlich and Temkin isotherms (Mead, 1981).

The Langmuir isotherm is described by the equation $\mathrm{Q}=\mathrm{Q}_{\max }{ }^{*} \mathrm{~K}_{\mathrm{L}}{ }^{*} \mathrm{c} /\left(1+\mathrm{K}_{\mathrm{L}}{ }^{*} \mathrm{c}\right)$, where $\mathrm{Q}$ is the concentration of the adsorbed anion $\left(\mathrm{mmol} \mathrm{kg}^{-1}\right), \mathrm{c}$ is the concentration in the liquid phase at equilibrium ( $\mu \mathrm{mol} \mathrm{L}-1), K_{L}$ is a constant related to the adsorption energy and $\mathrm{Q}_{\max }\left(\mathrm{mmol} \mathrm{kg}^{-1}\right)$ is the maximum adsorption capacity. The Langmuir model assumes the adsorption of a monolayer, that all the adsorption sites have the same adsorption energy and that there is no interaction among the adsorbed molecules (or ions) (Goldberg, 2005).

The Freundlich isotherm is described by the equation $\mathrm{Q}=\mathrm{K}_{\mathrm{F}}{ }^{*} \mathrm{c}^{\mathrm{n}}$, where $\mathrm{Q}$ and $\mathrm{c}$ have the same meaning as in the Langmuir equation, $\mathrm{K}_{\mathrm{F}}$ is the adsorption constant and $\mathrm{n}$ is a constant whose value varies between 0 and 1 . The Freundlich model assumes that the adsorption surface is heterogeneous and that the adsorption energy decreases exponentially as the concentration in the adsorbed phase increases. It does not predict an adsorption maximum (Goldberg, 2005).

The Temkin isotherm is described by the equation $\mathrm{Q}=(\mathrm{RT} / \mathrm{b}) * \ln (\mathrm{Ac})$ or $\mathrm{Q}=\mathrm{B} * \ln (\mathrm{Ac})$, where $\mathrm{Q}$ and $\mathrm{c}$ have the same meaning as in the Langmuir equation, $\mathrm{R}$ is the ideal gas constant $(8.314 \mathrm{~J}$ $\mathrm{mol}^{-1} \mathrm{~K}^{-1}$ ), $\mathrm{T}$ is the absolute temperature (in our case $293 \mathrm{~K}$, that is $20^{\circ} \mathrm{C}$ ) and $\mathrm{A}$ and $\mathrm{b}$ are constants related to the heat of adsorption. It considers that the adsorption surface is heterogeneous and that the adsorption energy decreases linearly with the concentration in the adsorbed phase. There is no maximum adsorption (Goldberg, 2005).

\section{RESULTS}

P sorption was very high in both the silandic and the vitric Andosols. In both soils, phosphorus sorption increased continuously as the phosphorus concentration in the equilibrating solution increased. P sorbed reached $47.7 \mu \mathrm{mol} \mathrm{P} \mathrm{g}{ }^{-1}$ in the silandic Andosol (Rwanda) and $41.6 \mu \mathrm{mol} \mathrm{P}$ $\mathrm{g}^{-1}$ in the vitric Andosol (São Tomé) for a P concentration of $3.2 \mathrm{mmol} \mathrm{L}^{-1}\left(100 \mathrm{mg} \mathrm{L}^{-1}\right)$ in the equilibrating solution. The percent sorbed $\mathrm{P}$ values (Table 2) ranged from 77.0 to 98.1 in the silandic Andosol (Rwanda) and from 65.6 to 95.9 in the vitric Andosol (São Tomé). The highest percentages corresponded to $10-20 \mathrm{mg} \mathrm{P} \mathrm{L}^{-1}$ in the equilibrating solution (Figure 1).

The sorption isotherms for both soils (Figure 2) did not fit the Langmuir or Freundlich models. On the contrary, they fitted the Temkin model $\left(\mathrm{r}^{2}=0.9702\right.$ for the vitric Andosol and 0.9770 for the silandic Andosol). The fitted equations were $Q=9.6843 \ln (0.2519 \mathrm{c})$ for the silandic Andosol and $\mathrm{Q}=8.3025 \ln (0.1367 \mathrm{c})$ for the vitric Andosol. Alternatively, the experimental 
192 points can be adjusted to two straight lines, the first with steep slope and the second with gentle 193 slope:

194

195

196

197

198

199

200

201

202

203

204

205

206

207

208

209

210

211

212

213

214

215

216

217

218

219

220

221

222

223

224

225

226

$\mathrm{Q}=0.3792 \mathrm{c} ; \mathrm{Q}=0.0197 \mathrm{c}+33.363$ for the silandic Andosol (Figure 3).

$\mathrm{Q}=0.3268 \mathrm{c} ; \mathrm{Q}=0.0178 \mathrm{c}+22.453$ for the vitric Andosol (Figure 4).

The $\mathrm{P}$ desorption was always less than $21 \%$ of the $\mathrm{P}$ sorbed in both soils (Table 2 ). The desorption isotherms (Figures 3 and 4 ) also fitted the Temkim model. The fitted equations were $\mathrm{Q}=22.014 \ln (0.1286 \mathrm{c}), \mathrm{r}^{2}=0.9448$ for the silandic Andosol and $\mathrm{Q}=15.436 \ln (0.1034 \mathrm{c})$, $\mathrm{r}^{2}=0.9855$ for the vitric Andosol.

\section{DISCUSSION}

The concern raised by the sorption of phosphate by soils has a double aspect: agronomic and environmental. Phosphorus is an essential nutrient, so its availability in agricultural soils is crucial for plant development. On the other hand, the existence of excess phosphorus gives rise to its export to aquatic environments, where it can be the cause of eutrophication processes. In soils poor in available phosphorus, like those in the present study (Table 1), the main concern is the availability of this macronutrient, which can be reduced by its adsorption by soil components, in particular non-crystalline materials. A strong retention is an undesirable process, particularly if poorly reversible. On the contrary, in over-fertilized soils phosphorus sorption is a desirable process, as it protects aquatic environments from pollution.

The highest values of $\mathrm{P}$ sorption by the studied soils are comparable to the $\mathrm{P}$ sorption maxima reported for some volcanic soils in Indonesia (Van Ranst et al., 2004) or Azores, Portugal (Auxtero et al., 2008). The P sorption is somewhat higher in the silandic Andosol, richer in oxalate-extractable aluminium and iron (Table 1), compared to the vitric Andosol. The $\mathrm{pH}$ in $\mathrm{NaF}$ higher than 10 in the silandic Andosol indicates high phosphate fixation by allophane or imogolite (Sanchez et al., 2003). On the other hand, the remarkable P sorption by the vitric Andosol may be related to its richness in dithionite-extractable iron (Table 1), higher than the threshold value established by Sanchez et al. (2003) for high phosphate fixation by iron and aluminium oxides. Several authors have reported a strong correlation between P sorption and Fe and Al extracted by acid oxalate (Monterroso Martinez et al., 1996; Van Ranst et al., 2004), while others suggest that crystalline Fe is more important for $\mathrm{P}$ adsorption than amorphous $\mathrm{Fe}$ (Auxtero et al., 2008).

The $\mathrm{P}$ adsorptions at low $\mathrm{P}$ concentrations for the two Andosols were both higher than the values reported by Duffera and Robarge (1999) for an Ustivitrand (vitric Andosol) developed from volcanic ash in Ethiopia. It should be noted that the soil used by these researchers was formed in a climate dryer than that prevailing in the locations of the soils of the present study and had 
227

228

229

230

231

232

233

234

235

236

237

238

239

240

241

242

243

244

245

246

247

248

249

250

251

252

253

254

255

256

257

258

259

260

261

262

263

significantly lower concentrations of $\mathrm{Fe}_{\mathrm{d}}$ and $\mathrm{Al}_{\mathrm{d}}(1.6 \%$ and $0.15 \%$, respectively). Furthermore, these authors studied a much lower range of concentrations than the one used in the present work.

By contrast, when comparisons are made with an Andosol developed from volcanic ash in Tanzania (Gimsing et al., 2007), it is found that the values of $\mathrm{P}$ adsorption are quite similar. The similarity with the silandic Andosol is not surprising, since the $\mathrm{Al}_{\mathrm{o}}$ concentration of the Tanzanian soil and the Rwanda silandic Andosol are comparable, although the concentrations of $\mathrm{Fe}_{\mathrm{o}}, \mathrm{Al}_{\mathrm{d}}$ and $\mathrm{Fe}_{\mathrm{d}}$ of the Tanzanian soil were considerably lower than those of both Andosols in the present study.

Interestingly, the P adsorption by an Andosol of the Bambouto Mountains (West Cameroon), in the Cameroon Hot Line (Siewé et al., 2008), very close to the São Tomé Andosol, was very similar to those of the Andosols in the present study, with a maximum of $4.75 \mathrm{mg} \mathrm{PO}_{4} \cdot \mathrm{g}^{-1}(50$ mmol. $\left.\mathrm{kg}^{-1}\right)$.

The high $\mathrm{P}$ sorption, particularly in the silandic Andosol, indicates that this element will be retained to a large extent in a non-available form. In these soils, an efficient management of phosphate fertilization is crucial, with high applications of slow-release phosphorus fertilizers or repeated localised applications of small quantities of $P$ fertilizers (Arduino et al., 1993). Organic substances, such as humic and fulvic acids or low molecular weight organic acids, compete with phosphate for adsorption sites (Sibanda and Young, 1986; Antelo et al., 2007); therefore, organic substances may significantly reduce phosphate adsorption and a sound management of organic matter and crop residues in phosphate adsorbing soils can help to improve phosphorus availability (Zhu et al., 2018).

Unlike the present study, in other research conducted for Andosols (Van Ranst et al., 2004; Auxtero et al., 2008) the best fit corresponded to Langmuir isotherms. Both the Langmuir and Freundlich models well describe P sorption on a variety of Australian soils (Singh and Gilkes, 1991), Thai Oxisols and Ultisols (Wisawapipat et al., 2009), soils developed from basic rocks in Portugal (Horta et al., 2013), and forest and vineyard soils from Galicia, Spain (Romar-Gasalla et al., 2016). The Langmuir, Freundlich and Temkin models can be used to describe P sorption on various Chinese soils (Wang et al., 2013). The Langmuir model described satisfactorily the $P$ adsorption by four soils from Ethiopia, including an Andosol (Duffera and Robarge, 1999), as well as by four variable-charge tropical soils from Tanzania, including an Andosol developed from volcanic ash (Gimsing et al., 2007). The phosphate adsorption by an Andosol of the Bambouto Mountains (West Cameroon) was also in agreement with the Langmuir model (Siewé et al., 2008).

The Langmuir equation is based on the assumption that the affinity of the surface for the adsorbate remains constant throughout the adsorption process. However, the adsorption of phosphate (and of other specifically adsorbed anions) increases the negative charge of the 
264

265

266

267

268

269

270

271

272

273

274

275

276

277

278

279

280

281

282

283

284

285

286

287

288

289

290

291

292

293

294

295

296

297

298

adsorbing surface, so that the adsorption of additional phosphate ions becomes increasingly difficult (Barrow, 1978). For this reason, the Langmuir equation only describes adsorption for low solution concentrations (Barrow, 1978; Goldberg, 2005). The Freundlich equation, which assumes that the affinity of the surface for the adsorbate decreases exponentially as the adsorption progresses, also describes well the adsorption at low solution concentrations (Barrow, 1978; Goldberg, 2005). The Temkin equation, which assumes that the affinity of the surface for the adsorbate decreases linearly as the adsorption progresses, is valid for an intermediate range of concentrations (Goldberg, 2005). The different ranges of concentration may explain the discrepancy between the present study and other similar research.

The fits in the present study are consistent with the specific adsorption of phosphate anion and indicate that the sorbing surface is heterogeneous. The fitted model cannot predict a limit to $\mathrm{P}$ sorption. The fit to two straight lines would indicate the presence of two types of sorbing sites: at low $\mathrm{P}$ concentrations in the equilibrating solution, phosphate would be sorbed onto high energy sites; at higher concentrations in solution, phosphate would be sorbed also onto lower energy sites.

The higher values of the B and A Temkin constants for the silandic Andosol (9.6843 vs. 8.3025 and 0.2519 vs. 0.1367 , respectively) indicate higher sorption energy and higher sorption equilibrium constant, respectively.

The silandic Andosol presents not only higher sorption, but also lower percentage of desorption (Table 2). That is, in the silandic Andosol phosphate is retained to a greater extent and is harder to desorb, which is in agreement with the higher sorption energy.

The sorption and desorption isotherms (Figures 3 and 4) show a pronounced hysteresis: for a given value of the phosphorus concentration in the liquid phase, the concentration in the sorbed phase is greater during desorption. The irreversibility of phosphate sorption is comparable to that reported by Auxtero et al. (2008) for Azorean Andosols with high contents of allophane, $\mathrm{Al}_{\mathrm{o}}, \mathrm{Al}_{\mathrm{d}}$ and $\mathrm{Fe}_{\mathrm{d}}$.

\section{CONCLUSIONS}

Both the silandic Andosol of Rwanda and the vitric Andosol of São Tomé showed high phosphorus sorption, being the silandic Andosol the one which sorbs more and desorbs less. The sorption by the silandic Andosol is related to active aluminium and iron species, while crystalline iron and aluminium oxides are mainly responsible for sorption in the vitric Andosol.

The strong phosphate sorption by the studied soils is a serious limiting factor for plant growth, which requires a careful management of phosphorus fertilization, including an appropriate management of organic matter. 
The low levels of desorption in both soils indicate a low risk of phosphorus leaching losses.

300

301

302

303

304

305

306

307

308

309

310

311

312

313

314

315

316

317

318

319

320

321

322

323

324

325

326

327

328

329

330

331

332

333

334

335

336

337

338

339

340

341

342

\section{REFERENCES}

Adegoke, H. I., Adekola, F. A., Fatoki, O. S., and Ximba, B. J. (2013). Sorptive Interaction of Oxyanions with Iron Oxides: A Review. Polish Journal of Environmental Studies 22, 724.

Adepoju, A. Y. (1993). Evaluation of P-sorption capacity of forest and savanna soils of Nigeria. Tropical Agriculture 70, 127-130.

Adetunji, M. T. (1997). Phosphorus sorption capacity of low activity clay soils of South Western Nigeria and its usefulness in evaluating P requirement of rice. Nutrient Cycling in Agroecosystems 47, 181-188.

Antelo, J., Arce, F., Avena, M., Fiol, S., Lopez, R., and Macias, F. (2007). Adsorption of a soil humic acid at the surface of goethite and its competitive interaction with phosphate. Geoderma 138, 12-19.

Arduino, E., Barberis, E., Badamchian, B., and Rooyani, F. (1993). Phosphorus status of certain agricultural soils of Lesotho, Southern Africa. Communications in Soil Science and Plant Analysis 24, 1021-1031.

Auxtero, E., Madeira, M., and Sousa, E. (2008). Phosphorus sorption maxima and desorbability in selected soils with andic properties from the Azores, Portugal. Geoderma 144, 535544.

Deruelle, B., Ngounouno, S., and Demaiffe, D. (2007). The 'Cameroon Hot Line' (CHL): A unique example of active alkaline intraplate structure in both oceanic and continental lithospheres. Comptes Rendus Geoscience 339, 589-600.

Duffera, M., and Robarge, W. P. (1999). Soil characteristics and management effects on phosphorus sorption by highland plateau soils of Ethiopia. Soil Science Society of America Journal 63, 1455-1462.

Frossard, E., Brossard, M., Feller, C., and Rouiller, J. (1992). Phosphate fixing capacity of some low activity clay soils. Canadian Journal of Soil Science 72, 135-143.

Garcia-Rodeja, E., Novoa, J. C., Pontevedra, X., Martinez-Cortizas, A., and Buurman, P. (2004). Aluminium fractionation of European volcanic soils by selective dissolution techniques. Catena 56, 155-183.

García-Rodeja, E., Nóvoa, J. C., Pontevedra, X., Martínez-Cortizas, A., and Buurman, P. (2007). Aluminium and iron fractionation of European volcanic soils by selective dissolution techniques. In "Soils of Volcanic Regions in Europe" (Ó. Arnalds, H. Óskarsson, F. Bartoli, P. Buurman, G. Stoops and E. García-Rodeja, eds.), pp. 325-351. Springer Berlin Heidelberg.

Gasparatos, D., Haidouti, C., Haroulis, A., and Tsaousidou, P. (2006). Estimation of phosphorus status of soil Fe-enriched concretions with the acid ammonium oxalate method. Communications in Soil Science and Plant Analysis 37, 2375-2387.

Gichangi, E. M., Mnkeni, P. N. S., and Muchaonyerwa, P. (2008). Phosphate sorption characteristics and external P requirements of selected South African soils. Journal of Agriculture and Rural Development in the Tropics and Subtropics 109, 139-149.

Gimsing, A. L., Szilas, C., and Borggaard, O. K. (2007). Sorption of glyphosate and phosphate by variable-charge tropical soils from Tanzania. Geoderma 138, 127-132. 
343
Goldberg, S. (2005). Equations and models describing adsorption processes in soils. In "Chemical Processes in Soils" (M. A. Tabatabai and D. L. Sparks, eds.), pp. 489-517. Soil Science Society of America, Madison, WI.

Goldberg, S., and Johnston, C. T. (2001). Mechanisms of arsenic adsorption on amorphous oxides evaluated using macroscopic measurements, vibrational spectroscopy, and surface complexation modeling. Journal of Colloid and Interface Science 234, 204-216.

Hashimoto, Y., Kang, J., Matsuyama, N., and Saigusa, M. (2012). Path analysis of phosphorus retention capacity in allophanic and non-allophanic Andisols. Soil Science Society of America Journal 76, 441-448.

Henry, P. C., and Smith, M. F. (2003). A single point sorption test for the routine determination of the phosphorus requirement of low to moderate P-fixing soils. South African Journal of Plant and Soil 20, 132-140.

Horta, C., Monteiro, F., Madeira, M., and Torrent, J. (2013). Phosphorus sorption and desorption properties of soils developed on basic rocks under a subhumid Mediterranean climate. Soil Use and Management 29, 15-23.

Jiang, X., Peng, C., Fu, D., Chen, Z., Shen, L., Li, Q., Ouyang, T., and Wang, Y. (2015). Removal of arsenate by ferrihydrite via surface complexation and surface precipitation. Applied Surface Science 353, 1087-1094.

Kumar, R., Kumar, R., Mittal, S., Arora, M., and Babu, J. N. (2016). Role of soil physicochemical characteristics on the present state of arsenic and its adsorption in alluvial soils of two agri-intensive region of Bathinda, Punjab, India. Journal of Soils and Sediments 16, 605-620.

Kuo, S. (1996). Phosphorus. In "METHODS OF SOIL ANALYSIS PART 3-CHEMICAL METHODS" (D. L. Sparks, A. L. Page, P. A. Helmke and R. H. Loeppert, eds.), pp. 869919. Soil Science Society of America, Madison, WI.

Loganathan, P., Isirimah, N. O., and Nwachuku, D. A. (1987). Phosphorus sorption by Ultisols and Inceptisols of the Niger Delta in Southern Nigeria. Soil Science 144, 330-338.

Mead, J. A. (1981). A comparison of the Langmuir, Freundlich and Temkin equations to describe phosphate adsorption properties of soils. Australian Journal of Soil Research 19, 333-342.

Monterroso Martinez, C., Fernandez-Marcos, M. L., and Alvarez Rodriguez, E. (1996). Factors influencing phosphorus adsorption in mine soils in Galicia, Spain. Science of the Total Environment 180, 137-145.

Nanzyo, M. (2002). Unique Properties of Volcanic Ash Soils. Global Environmental Research 6, 99-112.

Neall, V. E. (2009). Volcanic soils. In "Land use, land cover and soil sciences" (W. H. Verheye, ed.), Vol. VII, pp. 23-45. EOLSS Publishers, Oxford, UK.

Nwoke, O. C., Vanlauwe, B., Diels, J., Sanginga, N., Osonubi, O., and Merckx, R. (2003). Assessment of labile phosphorus fractions and adsorption characteristics in relation to soil properties of West African savanna soils. Agriculture Ecosystems \& Environment 100, 285-294.

Parfitt, R., and Childs, C. (1988). Estimation of forms of Fe and Al - a review, and analysis of contrasting soils by dissolution and Mossbauer methods. Soil Research 26, 121-144.

Parfitt, R. L. (1979). Anion Adsorption by Soils and Soil Materials. In "Advances in Agronomy" (N. C. Brady, ed.), Vol. Volume 30, pp. 1-50. Academic Press. 
Romar-Gasalla, A., Rivas-Perez, I. M., Paradelo-Nunez, R., Carlos Novoa-Munoz, J., AriasEstevez, M., Fernandez-Sanjurjo, M. J., Alvarez-Rodriguez, E., and Nunez-Delgado, A. (2016). Phosphorus retention on forest and vineyard soil samples, mussel shell, pinesawdust, and on pyritic, granitic and waste materials. Geoderma 280, 8-13.

Sanchez, P. A., Palm, C. A., and Buol, S. W. (2003). Fertility capability soil classification: a tool to help assess soil quality in the tropics. Geoderma 114, 157-185.

Sibanda, H. M., and Young, S. D. (1986). Competitive adsorption of humus acids and phosphate on goethite, gibbsite and 2 tropical soils. Journal of Soil Science 37, 197-204.

Siewe, J. M., Djoufac, W. E., Bitom, D., Figueras, F., Djomgue, P., Njopwouo, D., and Azinwi, P. T. (2008). Andosols of the Bambouto Mountains (West Cameroon): characteristics, superficial properties - study of the phosphate ions adsorption. The Open Inorganic Chemistry Journal 2, 106-115.

Singh, B., and Gilkes, R. (1991). Phosphorus sorption in relation to soil properties for the major soil types of South-Western Australia. Soil Research 29, 603-618.

Valle, S. R., Carrasco, J., Pinochet, D., Soto, P., and Mac Donald, R. (2015). Spatial distribution assessment of extractable $\mathrm{Al},(\mathrm{NaF}) \mathrm{pH}$ and phosphate retention as tests to differentiate among volcanic soils. Catena $127,17-25$.

Van Ranst, E., Utami, S. R., Vanderdeelen, J., and Shamshuddin, J. (2004). Surface reactivity of Andisols on volcanic ash along the Sunda arc crossing Java Island, Indonesia. Geoderma 123, 193-203.

Wang, X.-Y., Zhang, L.-P., Zhang, F.-F., Zhang, H.-S., and Mei, D.-L. (2013). Phosphorus Adsorption by Soils from Four Land Use Patterns. Asian Journal of Chemistry 25, 282286.

Wisawapipat, W., Kheoruenromne, I., Suddhiprakarn, A., and Gilkes, R. J. (2009). Phosphate sorption and desorption by Thai upland soils. Geoderma 153, 408-415.

Woumfo, E. D., Siewe, J. M., and Njopwouo, D. (2015). A fixed-bed column for phosphate removal from aqueous solutions using an andosol-bagasse mixture. Journal of Environmental Management 151, 450-460.

Zhu, J., Li, M., and Whelan, M. (2018). Phosphorus activators contribute to legacy phosphorus availability in agricultural soils: A review. Science of the Total Environment 612, 522537. 
Figure 1 (on next page)

Percentage of P sorption for various $\mathrm{P}$ concentrations in the equilibrating solution 


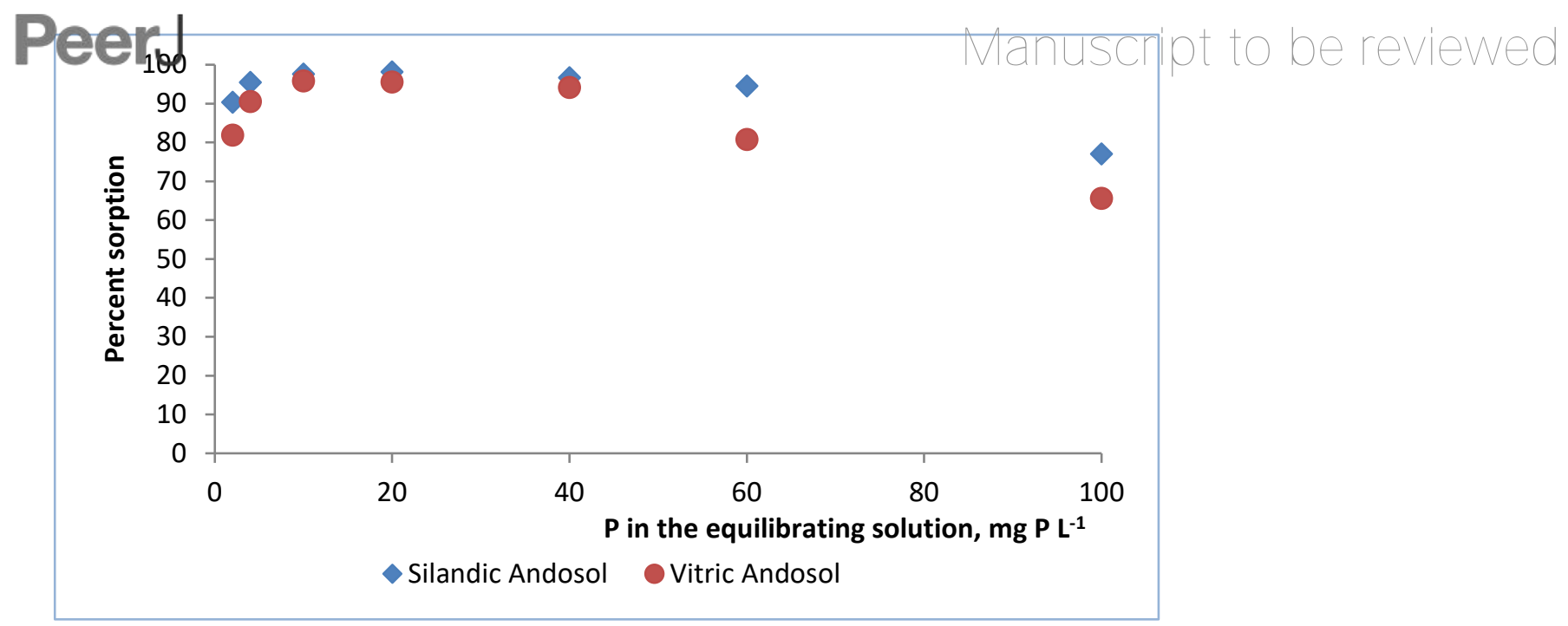


Figure 2 (on next page)

Sorption isotherms fitted to the Temkin model 


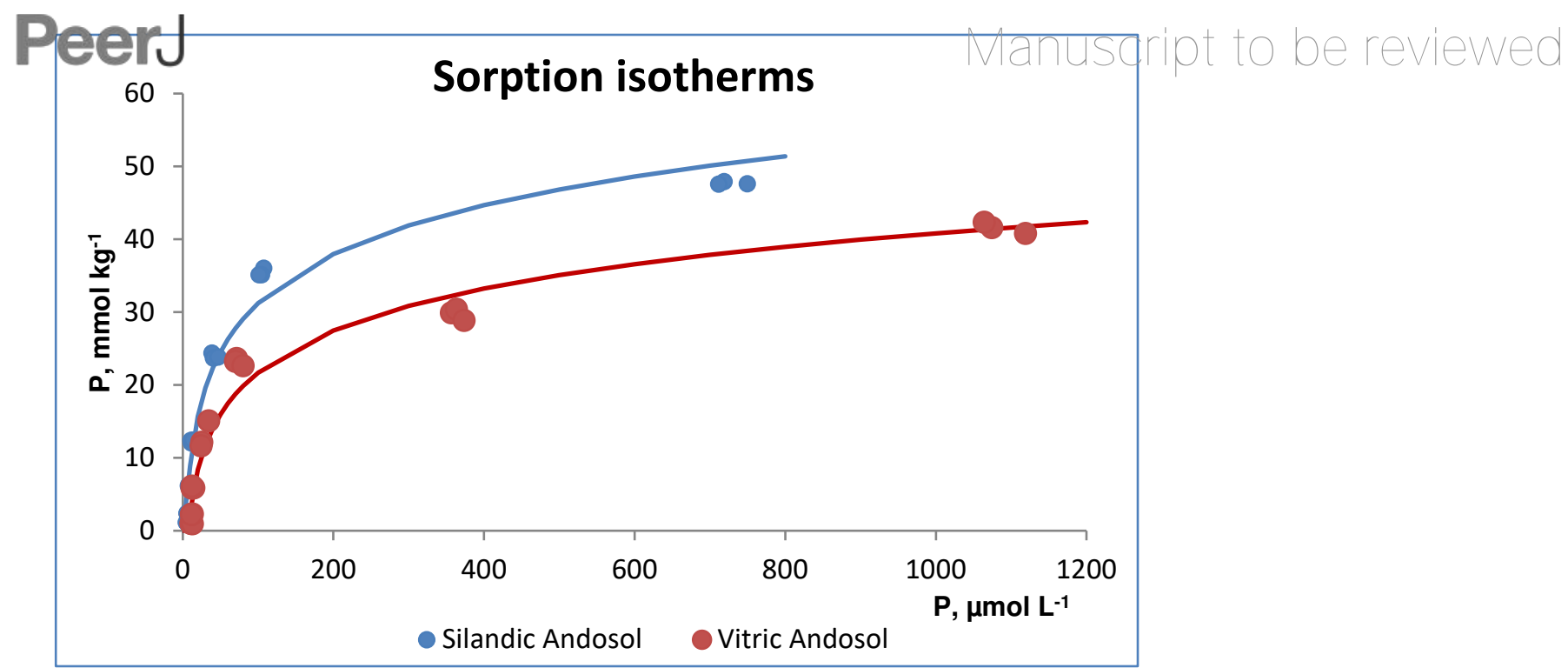


Figure 3 (on next page)

Sorption and desorption isotherms for the silandic Andosol 


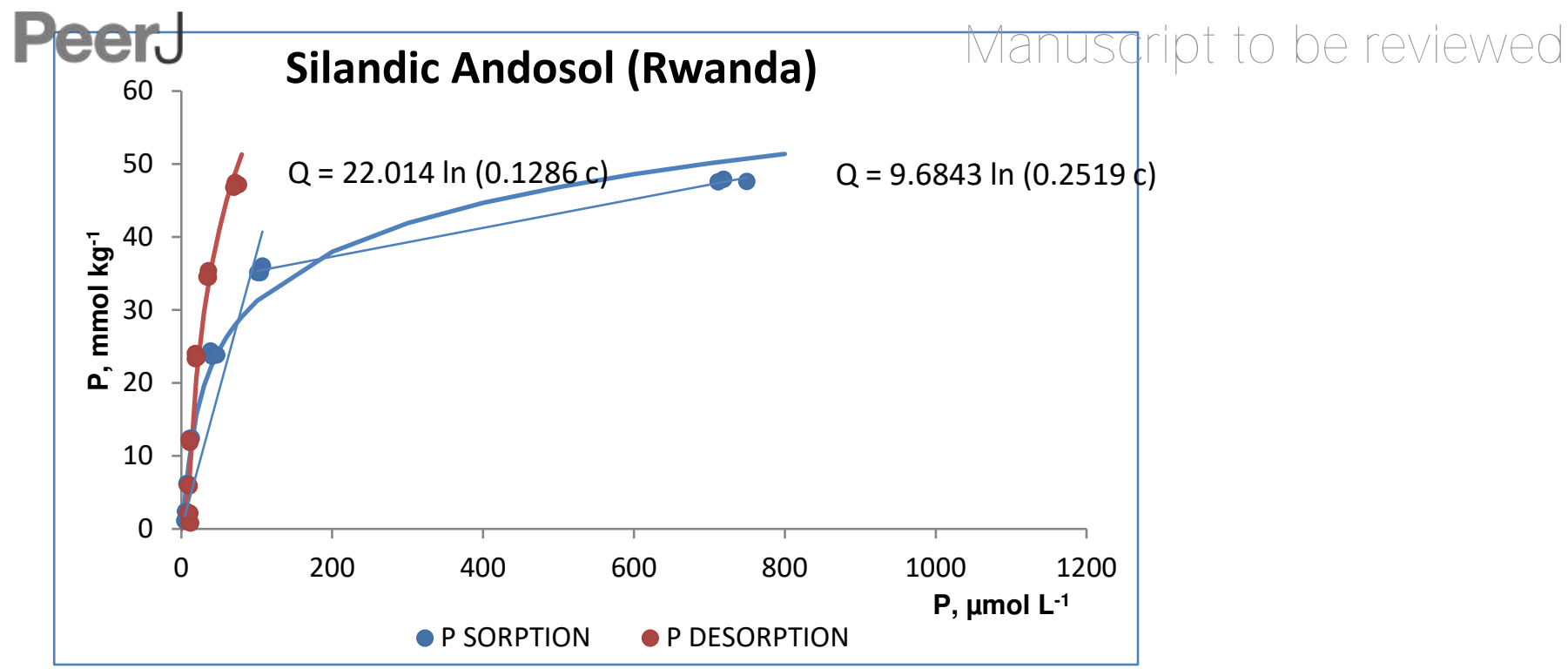


Figure 4 (on next page)

Sorption and desorption isotherms for the vitric Andosol 


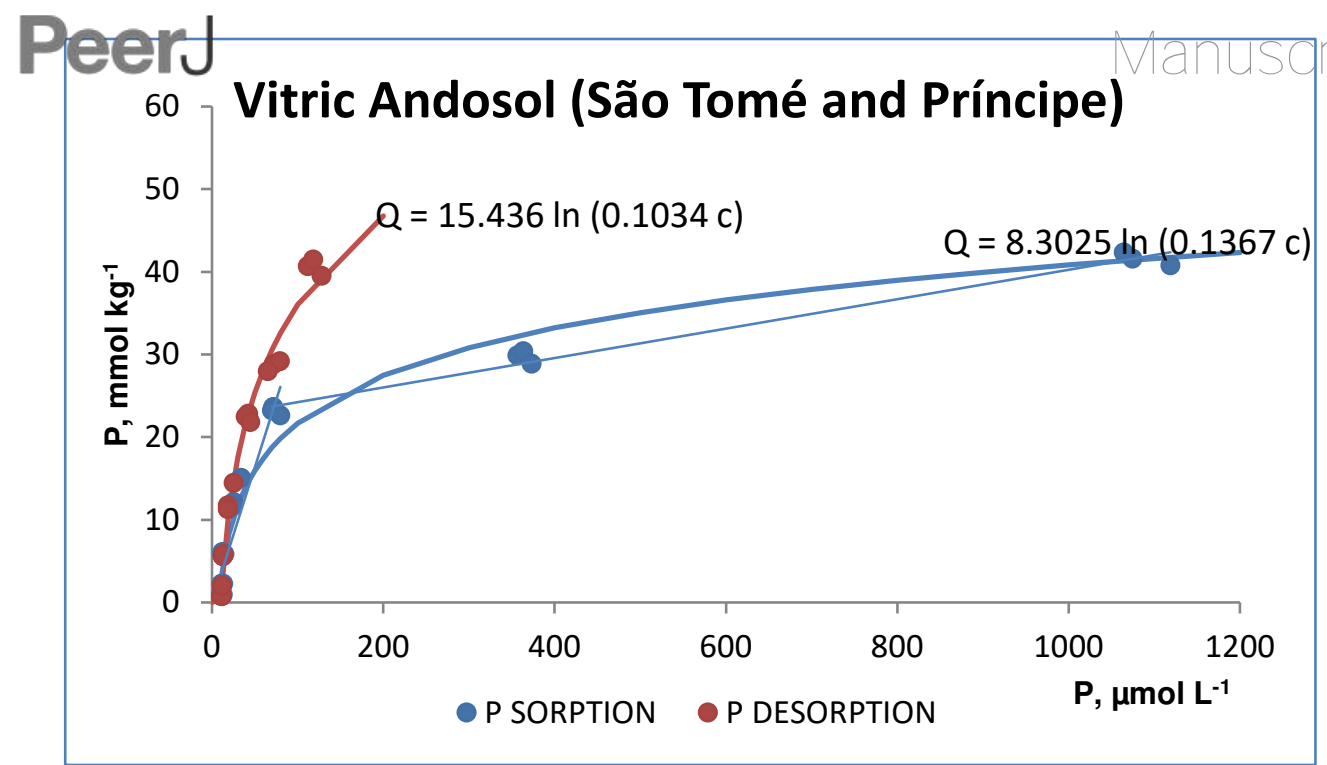




\section{Table $\mathbf{1}$ (on next page)}

Location, $\mathrm{pH}$, organic carbon, texture, available $\mathrm{P}$, aluminium and iron extracted by acid oxalate and by dithionite-citrate and $\mathrm{pH}$ in $\mathrm{NaF}$ of the studied soils 
1 Table 1. Location, $\mathrm{pH}$, organic carbon, texture, available $\mathrm{P}$, aluminium and iron extracted by acid oxalate 2 and by dithionite-citrate and $\mathrm{pH}$ in $\mathrm{NaF}$ of the studied soils.

\begin{tabular}{|c|c|c|c|c|c|c|c|c|c|c|c|}
\hline Soil & Location & $\begin{array}{l}\text { Altitude } \\
\text { (m) }\end{array}$ & $\mathrm{pH}$ & $\begin{array}{l}\mathrm{C} \\
(\%)\end{array}$ & Texture & $\begin{array}{l}\text { Mehlich- } \\
3 \mathrm{P} \\
\left(\mathrm{mg} \cdot \mathrm{kg}^{-1}\right)\end{array}$ & $\begin{array}{l}\mathrm{Fe}_{\mathrm{o}} \\
(\%)\end{array}$ & $\begin{array}{l}\mathrm{Al}_{\circ} \\
(\%)\end{array}$ & $\begin{array}{l}\mathrm{Fe}_{\mathrm{d}} \\
(\%)\end{array}$ & $\begin{array}{l}\mathrm{Al}_{\mathrm{d}} \\
(\%)\end{array}$ & $\mathrm{pH}_{\mathrm{NaF}}$ \\
\hline $\begin{array}{l}\text { Silandic } \\
\text { Andosol }\end{array}$ & $\begin{array}{l}01366^{\prime} 32^{\prime \prime} \mathrm{S} \\
29 \circ 32^{\prime} 57^{\prime \prime} \mathrm{E}\end{array}$ & 311 & 5.60 & 6.18 & $\begin{array}{l}\text { Sandy } \\
\text { loam }\end{array}$ & 32.2 & 3.46 & 2.48 & 4.60 & 1.81 & 11.07 \\
\hline $\begin{array}{l}\text { Vitric } \\
\text { Andosol }\end{array}$ & $\begin{array}{l}00-20^{\prime} 00^{\prime \prime} \mathrm{N}, \\
06-39^{\prime} 00^{\prime \prime} \mathrm{E}\end{array}$ & 2,368 & 6.30 & 7.46 & $\begin{array}{l}\text { Silty } \\
\text { loam }\end{array}$ & 13.5 & 1.11 & 0.40 & 7.84 & 1.74 & 8.39 \\
\hline
\end{tabular}

$3 \mathrm{Fe}_{0}, \mathrm{Al}_{0}$ : Fe and $\mathrm{Al}$ extracted by acid ammonium oxalate (Blakemore, 1983)

$4 \mathrm{Fe}_{\mathrm{d}}, \mathrm{Al}_{\mathrm{d}}$ : Fe and $\mathrm{Al}$ extracted by dithionite-citrate (Holmgren, 1967)

5 
Table 2 (on next page)

Percent sorption and desorption in both studied soils 
1 Table 2. Percent sorption and desorption in both studied soils

\begin{tabular}{lllll}
\hline & \multicolumn{3}{c}{ Vitric Andosol } & \multicolumn{2}{c}{ Silandic Andosol } \\
\hline $\begin{array}{l}P \text { in the equilibrating solution }\left(\mathrm{mg} \mathrm{L}^{-}\right. \\
\text {1) }\end{array}$ & $\begin{array}{l}\% \\
\text { sorption }\end{array}$ & $\begin{array}{l}\text { desorption } \\
\text { derption }\end{array}$ & $\begin{array}{l}\% \\
\text { sesorption }\end{array}$ \\
\hline 2 & 81.9 & 21.0 & 90.4 & 19.6 \\
4 & 90.5 & 10.1 & 95.5 & 8.4 \\
10 & 95.9 & 4.2 & 97.6 & 3.2 \\
20 & 95.6 & 3.3 & 98.1 & 1.8 \\
40 & 94.2 & 3.4 & 96.7 & 1.5 \\
60 & 80.8 & 3.6 & 94.5 & 1.7 \\
100 & 65.6 & 2.4 & 77.0 & 1.2 \\
\hline
\end{tabular}

2 